\title{
CRITICAL PERSPECTIVES ON THE USE OF BRANDING MODELS IN APPROACHING PLACES
}

\author{
$\begin{array}{ll}\text { V.-A. BRICIU } & \text { A. BRICIU } \\ \end{array}$
}

\begin{abstract}
This article investigates in depth the characteristics of the interdisciplinary social theory of neo-Marxism, as a moderate response with socio-economic influences on the paradigm of postmodern brand management (defined by the theory of iconic brands and cultural branding as a model by which brands become icons through creative interaction with their environment, on the one hand, and the anti-capitalist, anti-corporate and anti-branding movement, on the other), both included in a constructivist-interpretivist paradigmatic scheme. This type of critical approach, through reinterpretations and extensions of the ideas of social philosopher Karl Marx, replaces the marketing paradigm as a model of "social engineering" in the words of Douglas B. Holt and proposes new perspectives on the concept of consumer culture in which brands are seen as forms of intangible capital, with the main demands proposed by the antibranding movement being highlighted, as well as the criticisms brought to "consumer culture".
\end{abstract}

Keywords: brands, intangible capital, postmodern brand management, anti-branding, commodification of places.

\section{Introduction}

Over time, the term "brand" has generated and acquired a whole series of meanings and interpretations, with different specialists trying to find a more precise definition for it (Aaker, 1996; de Chernatony, 1999; Kotler, 2000). The variety of forms that this term can take and the multidisciplinary perspectives in approaching brands and expressing the identity of places in fields such as economics, psychology, public relations, sociology or cultural studies (Briciu and Briciu, 2020a) have structured and delimited this new theoretical and practical field more clearly. Thus, viewed from an objective perspective, the term "brand" can be identified and defined by various theoretical and methodological forays, following the fundamental works that open the field of

\footnotetext{
${ }^{1}$ Transilvania University of Braşov, victor.briciu@unitbv.ro, corresponding author

2 Transilvania University of Braşov.
} 
branding (Anholt, 2005a; Olins, 2006; Anholt, 2007) and the issue of place branding (Anholt, 2005b, 2007, 2010, Freire, 2005; Kerr, 2006; Skinner and Kubacki, 2007; Govers and Go, 2009).

However, as Heding et al. (2009, p. 21) observed, "perhaps due to the elusive nature of the brand, the term 'brand paradigm' is often used at random in the branding discipline". This task of clarifying and homogenizing a main paradigm is difficult due to the inconsistency of conceptualizing the terms brand, branding and place brand and the proliferation of a variable and inaccurate terminology related to place branding. There is also competition between theorists and practitioners in establishing the characteristics and the differences between the terms. Second, although there is a clear delimitation between products and places, "there has been little examination of traditional branding models in light of the differences and development of hypotheses about how place branding processes may be altered" (Pryor and Grossbart, 2007, p. 293).

In order to have a much broader vision of brands and to understand them, they need to be analyzed and viewed from several perspectives (Briciu and Briciu, 2020a). These could bring us answers to the gradual change of brands, from the economic model of consumer branding initially defined by the simple provision of information for utilitarian purposes (in the case of proto-brands) (Briciu and Briciu, 2016), of the origin and the quality of the products and services, expressing their transactional side, to the organizational or corporate communication model, through an identity approach, as an expression through which branding techniques have penetrated and redefined the organizational environment, crystallizing a socio-economic constructivism tradition.

Thus, specialists in the field highlighted four main perspectives in the treatment of brands, namely the corporate perspective, the consumer perspective, the cultural perspective and the critical perspective (Schroeder, 2015). These four perspectives demonstrate the interest developed in brands and research on this topic, with the purpose of identifying certain issues, such as: consumer culture or behavior, going beyond marketing issues (Kotler and Gertner, 2002) and emphasizing socio-cultural aspects (Garlitz, 2005).

The cultural perspective, according to Schroeder (2015), considers that brands are more a part of culture, than a primary tool of the management activity. Brand research conducted from the cultural perspective covers a space between the strategic concepts of brand identity and the consumer interpretation of its image. This theoretical model tries to fill the gaps between the corporate perspective and the consumer perspective, emphasizing the history and heritage of that brand, the way it creates associations, meaning and value. It focuses on how brands create and share a common story and build a community. As cultural forms (Holt, 2004), brands evolve in line with changes in the historical, geographical and social context. Thus, cultural, ideological and political environments influence the process of building brands, and can be understood as reflections of people's ideologies, their lifestyle and their cultural values (Briciu and Briciu, 2020b).

In order to understand brands from a corporate perspective, it is important to refer to some of the most appreciated and well-known brands, such as: Apple, Disney, Google and McDonalds, as Schroeder (2015) considers. They are seen as corporate brands, 
rather than entities that belong to a corporation, each of which is valued more for their attribution to a particular brand, than for their usefulness or other functional aspects. From the corporate perspective, the equity models of the brand, its identity and image (Kavoura and Nechita, 2017) are essential for understanding issues such as brand DNA, its essence and evaluation (Briciu et al., 2019). We can also talk about brand culture within a corporation, which refers to how much an organization aligns with certain promoted values. From a corporate perspective, branding largely refers to communicating a message interpreted in accordance with the intention of the brand owner. The basic branding strategy involves the idea that branding decisions work together with other branding elements, such as: its essence, personality and positioning, brand execution, which includes advertising, promotion and Social Media activities (Briciu and Briciu, 2021).

Consumer research has shown that brands are interpreted in many ways, thus leading to a major reconsideration of how they work. According to Schroeder (2015), from the consumer's perspective, brands can be understood as "communicative objects". Cultural codes, ideological discourse, consumer background knowledge and rhetorical processes were mentioned as influences on branding and on consumer-brand relationships. Brand relationships include how consumers form connections and attachment to them, fostered by strategic brand communication and negotiated by consumers. Brand communities and brand tribes refer to groups of followers of a brand, who often come together, online or in person, to "stage" the favored brand. Brand communities are marked by common ideals about the brand, rituals and a sense of obligation to the brand.

Brands are equally viewed from a critical perspective. This type of vision is not necessarily associated with the negative impact that brands have, but rather with the way they impact and influence the world from a social, political and cultural standpoint, therefore this perspective highlights both positive and negative aspects related to brands. Schroeder (2015) considers that the critical perspective spreads an important point of view that shows how brands function aesthetically, ideologically and as political objectives, beyond their initial, strategic role.

\section{The Anti-branding Cultural Movement and the No Logo Manifesto}

In an article that has become a landmark of the cultural branding theory, Holt argues that what he calls the "postmodern branding paradigm" is built not on trying to impose or adopt certain consumer practices on individuals, but rather by offering brands as "cultural resources", and then capitalizing on what consumers produce with these resources: "the market today thrives on consumers [...], unruly bricoleurs who engage in nonconformist producerly consumption practices." (Holt, 2002, p. 88). Similarly, in her anti-branding manifesto "No Logo", Klein (2000) denounces brands (among other things) for "their tendency to colonize public space, insert themselves into all walks of life, and demand and capture attention and affect" (A. Arvidsson, 2005, p. 237). The same idea is portrayed by Castells (2000) that analyses "the impact of the globalization process on space, which shifts from a geographically well-defined local space to a space of multiple 
flows of capital, information, interactions, symbols, and technologies" (cited in Rezeanu et al., 2016, p. 5).

This new philosophy and the anti-globalization movement strongly attacked the notion of branding, focusing on the brand in particular - the most public, seductive and manipulative manifestation of the corporation, following "the idea developed by management theorists in the mid-1980s: that successful corporations must primarily produce brands, as opposed to products" (Klein, 2000, p. 25). That is why brands have reached "a high position in the pantheon of horrors created by the anti-capitalist and anti-corporate movement. N. Klein and those who think like her, have worked hard to demonize corporations such as Nike, Coca-Cola and several other companies equally known for the economic oppression of the poor in Third World countries, for the fact that they influence and undermine the education of children in the West, that their prices are too high for what they offer to their existing and potential customers, that they wash underprivileged people's brains to buy products they don't need or really want and that can harm them, as well as because they generally act like thugs, robbers and profiteers. This may be an exaggeration of the perspective presented in No Logo, but not by much" (Olins, 2006, p. 11).

Thus, a counterculture is formed around the idea that "the branding efforts of global consumer goods companies have spawned a societally destructive consumer culture" (Holt, 2002, p. 70).

But, according to Olins, "the weak point of N. Klein's anti-capitalist school is that it treats brands as if their only manifestation were corporate and commercial. Today, however, the influence, strategies and tactics of branding go far beyond these aspects. Branding plays an increasing role in politics, in defining nation, sports, culture and in the sector of volunteering activities" (Olins, 2006, p. 12), and the key notion regarding brands that No Logo supporters avoid or do not take into account is that "brands themselves are neither good nor bad; only the way, place and reason they are used are truly significant" (Olins, 2006, p. 12).

But in addition to ignoring branding in a wider world, the world beyond trade, Klein (2000) and the other protesters overlook another fundamental issue: "We like brands. If we didn't like them, we wouldn't buy them. We, the consumers, are the ones who decide which brand will be successful and which will not. Some brands thrive because people love them and cannot get enough of them. Other brands simply fail because people do not want them. They mean nothing to anyone" (Olins, 2006, p. 17).

In fact, observing a resemblance to neo-Marxist conceptions, "anti-globalists are not at all interested in the brands themselves. To them, brands are just simple symptoms of a capitalist system that supports an extremely uneven distribution of wealth, terrible exploitation and waste of finite resources. Brands, they claim, are the favorite weapon of these world destroyers. Brands offer the illusion of choice, thus creating more waste and more intense exploitation of increasingly scarce resources. Moreover, brands only offer options to people who have the money, the level of education and the information that is needed to make the decision to buy them. Poor people - that is, most of the world - must accept what is offered to them by global, exploitative and profitable companies" (Olins, 2006, pp. 11-12). 
This view is a clear example of what the economist Myrdal (1957 cited in Hospers, 2004) called the "Matthew effect", a phenomenon adopted according to an old biblical principle: "For whosoever hath, to him shall be given ... but whosoever hath not, from him shall be taken away even that he hath" (Matthew 13:12 cited in Hospers, 2004, p. 273) or in other words "the rich become richer, while the poor become poorer. In short, one might say that the saying 'success breeds success' applies to places as well" (Hospers, 2004, p. 273).

Olins (2006) launches a similar idea, in which the above-described effect is produced, in the author's opinion, by globalization, through fierce competition between nations, on concrete - quantifiable - aspects, attracted investment, exports and tourism. "These are aspects where winners and losers appear. The winners become richer and stronger, and the losers remain poor and weak" (Olins, 2006, p. 137). Therefore, each nation or place is now trying to promote its own values, history, culture and personality, projecting what might be called an idealistic self-image, but immediately recognizable for economic, commercial and political purposes.

The writings of the Frankfurt School (along with the most visible ideation of neoMarxists) are essential in shaping the idea of an "educated", if not "skeptical" consumer (Garlitz, 2005, p. 3), if we reconsider the ideas found in the anti-branding manifesto (Klein, 2000).

\section{The Neo-Marxist Critique of the Use of Branding Models in Approaching Places}

Constructivist studies examine how nation branding is involved in social power relations and try to examine the strategies and practices associated with a nation's branding from a historical point of view. These studies "problematize the tendency of nation branding to depoliticize and obscure the struggles and negotiations through which national identities are produced. They are also concerned with the commodification of national identities that nation branding implies." (Kaneva, 2011, p. 131)

As a neo-Marxist orientation, such a process of commodification begins with capital (Garlitz, 2005, p. 3). Criticism of the use of marketing strategies and the sale of areas on the market brings a "commercial change of regions", a "commodification of places", "the ongoing process, as opposed to the result, of moulding a place according to the logic of the market" (Lucarelli et al., 2021, p. 3).

Considering places as products, "authorities run the risk of neglecting the human aspect of areas, which may conflict with the public responsibilities of government. In practice, however, regions make extensive use of headline-grabbing slogans and promotion campaigns to put themselves on the map. Though the effect of this place marketing strategy is difficult to measure, it would seem that some places really have succeeded in developing a strong brand" (Hospers, 2004, p. 273). "The marketization" of contemporary society, especially of non-economic subsystems, such as the health system, education, art or science, "has been a hot topic of public debates as well as a subject of many empirical studies. [...] Since the market as a basic governance mechanism is primarily associated with the economic sub-system of modern society, marketization can be seen as the means by which other societal sub-systems are 
subjected to a deliberate policy of economizing." (Schimank and Volkmann, 2012, p. 37). In other words, "economizing" can be understood through economic considerations related to financial benefits and costs, in the case of specific societal subsystems or at the level of society as a whole.

From the perspective of Marxist theory, the "marketing" and "economizing" of modern society are not at all surprising. Because capitalist economy is "the center of society which dominates all other sub-systems it seems to be only natural that it extends its influence to the rest of society. Commodification is the Marxist term for this basic dynamic of capitalism" (Schimank and Volkmann, 2012, p. 37). It involves the transformation of goods and services, ideas and other entities, which would not normally be considered goods, into merchandise.

\section{Conclusions}

When looking at brands and the branding process, one can point out some main conclusions regarding their role and the theoretical perspectives in this article aimed at this broad field, so that the following ideas emerge: the brand concept has expanded far beyond the consumer market where it was born to enter the sphere of management (corporate branding), politics and the construction of place identities in a global perspective (Lemos Baptista et al., 2019); a brand does not only have the role of illustrating a certain product or service, but it also builds an attitude, creates a community and develops a sense of attachment; no matter how popular a brand is, it must stay relevant to consumers at all times in order to be able to compete, even if it is through excessive promotion; brands can perpetuate inequality between individuals and can be considered a form of employee exploitation.

\section{References}

Aaker, D. (1996). Building Strong Brands. New York: The Free Press.

Anholt, S. (2005a). Brand New Justice: How Branding Places and Products Can Help the Developing World, $2^{\text {nd }}$ Edition. Oxford: Butterworth-Heinemann.

Anholt, S. (2005b). Editorial: Some important distinctions in place branding. Place Branding, 1(2), 116-121, https://doi.org/10.1057/palgrave.pb.5990011.

Anholt, S. (2007). Competitive Identity: The New Brand Management for Nations, Cities and Regions. Hampshire: Palgrave Macmillan.

Anholt, S. (2010). Places. Identity, Image and Reputation. Hampshire: Palgrave Macmillan.

Arvidsson, A. (2005). Brands: A critical perspective. Journal of Consumer Culture, 5(2), 235-258, https://doi.org/10.1177/1469540505053093.

Briciu, A., \& Briciu, V.-A. (2020b). A Cultural Perspective on Brands and Symbol Affirmation. The Theory of Cultural and Iconic Branding Reviewed. Bulletin of the Transilvania University of Brasov, 13(62), 95-102, https://doi.org/10.31926/but.ssl.2020.13.62.1.10. 
Briciu, V.-A., \& Briciu, A. (2016). A Brief History of Brands and the Evolution of Place Branding. Bulletin of the Transilvania University of Brasov, 9(58), 137-142. Retrieved from http://webbut.unitbv.ro/bulletin/Series\%20VII/BULETIN\%20I/22_Briciu.pdf.

Briciu, V.-A., \& Briciu, A. (2020a). Multidisciplinary Perspectives in Approaching Brands and Expressing Place Identity. Bulletin of the Transilvania University of Brasov, 13(62), 283-290, https://doi.org/10.31926/but.ssl.2020.13.62.2.16.

Briciu, V.-A., \& Briciu, A. (2021). Social Media and Organizational Communication. In M. Khosrow-Pour D.B.A. (Ed.), Encyclopedia of Organizational Knowledge, Administration, and Technology (pp. 2609-2624). Hershey: IGI Global, http://doi:10.4018/978-1-79983473-1.ch180.

Briciu, V.-A., Demeter, R., Nechita, F., Kavoura, A. \& Briciu, A. (2019). A Proposed Online Platform for Ranking Place Brands Identity Characteristics of Official Tourism Websites. In A. Kavoura, E. Kefallonitis, A. Giovanis, Apostolos (Eds.), Strategic Innovative Marketing and Tourism. Springer Proceedings in Business and Economics (pp. 755-762). Cham: Springer, https://doi.org/10.1007/978-3-030-12453-3_87.

de Chernatony, L. (1999). Brand Management Through Narrowing the Gap Between Brand Identity and Brand Reputation. Journal of Marketing Management, 15(1-3), 157-179, https://doi.org/10.1362/026725799784870432.

Freire, J. R. (2005). Geo-branding, are we talking nonsense? A theoretical reflection on brands applied to places. Place Branding, 1(4), 347-362, https://doi.org/10.1057/palgrave.pb.5990033.

Garlitz, D. (2005). The Frankfurt School's Neo-Marxian Critiques of Capitalism and Consumer Culture. Retrieved from http://www.philosophyofculture.org/ frankfurt_school_consumer_culture_garlitz_2005.pdf.

Govers, R., \& Go, F. (2009). Place Branding. Glocal, Virtual and Physical Identities, Constructed, Imagined and Experienced. London: Palgrave Macmillan.

Heding, T., Knudtzen, C. F., \& Bjerre, M. (2009). Brand Management: Research, theory and practice. Taylor \& Francis e-Library.

Holt, D. B. (2002) Why Do Brands Cause Trouble? A Dialectical Theory of Consumer Culture and Branding. Journal of Consumer Research, 29, 70-90, https://www.jstor.org/stable/10.1086/339922.

Holt, D. B. (2004). How Brands Become Icons: The Principles of Cultural Branding. Boston: Harvard Business Press.

Hospers, G. J. (2004). Place marketing in Europe. Intereconomics, 39, 271-279, https://doi.org/10.1007/BF03031785.

Kaneva, N. (2011) Nation Branding: Toward an Agenda for Critical Research. International Journal of Communication, 5, 117-141. Retrieved from https://ijoc.org/index.php/ijoc/article/view/704.

Kavoura, A., \& Nechita, F. (2017). An Exploratory Study of Online Destination Images via User-Generated Content for Southeastern Rural Transylvania. In A. Királ'ová (Ed.), Driving Tourism through Creative Destinations and Activities (pp. 45-66). Hershey: IGI Global, http://doi:10.4018/978-1-5225-2016-0.ch003.

Kerr, G. (2006). From destination brand to location brand. Brand Management, 13(4-5), 276-283, https://doi.org/10.1057/palgrave.bm.2540271. 
Klein, N. (2000). No Logo: No Space, No Choice, No Jobs. London: Flamingo.

Kotler, Ph. (2000). Marketing Management. The Millenium Edition. Upper Saddle River: Prentice Hall.

Kotler, Ph., \& Gertner, D. (2002). Country as brand, product, and beyond: A place marketing and brand management perspective. Brand Management, 9(4-5), 249-261, https://doi.org/10.1057/palgrave.bm.2540076.

Lemos Baptista, J. M., Pocinho, M., \& Nechita, F. (2019). Tourism and Public Policy. Bulletin of the Transilvania University of Brasov, 12(61), 77-86, https://doi.org/10.31926/but.es.2019.12.61.1.11.

Lucarelli, A., Cassinger, C., \& Ågren, K. (2021). Continuity and discontinuity in the historical trajectory of the commercialising of cities: storying Stockholm 1900-2020, Business History, 1-27, https://doi.org/10.1080/00076791.2021.1979517

Olins, W. (2006). Despre brand [On Brand]. Bucharest: comunicare.ro.

Pryor, S., \& Grossbart, S. (2007). Creating meaning on main street: Toward a model of place branding. Place Branding and Public Diplomacy, 3(4), 291-304, https://doi.org/10.1057/palgrave.pb.6000080.

Rezeanu, C.-I., Briciu, A., Briciu, V.-A., Repanovici, A., \& Coman, C. (2016). The Influence of Urbanism and Information Consumption on Political Dimensions of Social Capital: Exploratory Study of the Localities Adjacent to the Core City from Brașov Metropolitan Area, Romania. PLOS ONE 11(1): e0144485, https://doi.org/10.1371/ journal.pone.0144485.

Schimank, U. \& Volkmann, U. (2012). Economizing and Marketization in a Functionally Differentiated Capitalist Society - A Theoretical Conceptualization. In U. Schimank \& U. Volkmann (Eds.), The Marketization of Society: Economizing the Non-Economic (pp. 37-63). Bremen: University of Bremen.

Schroeder, J.E. (Ed.). (2015). Brands: Interdisciplinary Perspectives, $1^{\text {st }}$ Edition. London: Routledge, https://doi.org/10.4324/9781315765808.

Skinner, H., \& Kubacki, K. (2007). Unravelling the complex relationship between nationhood, national and cultural identity, and place branding. Place Branding and Public Diplomacy, 3(4), 305-316, https://doi.org/10.1057/palgrave.pb.6000072. 